\title{
Cinta Abadi dalam Novel Laila Majnun Karya Nizami dan Novel Romeo Juliet Karya William Shakespeare Kajian Intertekstual
}

\author{
Desta Leila Kartika ${ }^{凶}$, Suseno, Uum Qomariyah \\ Jurusan Bahasa dan Sastra Indonesia, Fakultas Bahasa dan Seni, Universitas Negeri Semarang, \\ Indonesia
}

\begin{tabular}{l}
\hline Info Artikel \\
\hline Sejarah Artikel: \\
Diterima Februari 2018 \\
Disetujui April 2018 \\
Dipublikasikan Juli 2018 \\
\hline Keywords: \\
intertextual, eternity of love, \\
laila majnun, romeo juliet \\
\hline
\end{tabular}

\begin{abstract}
Abstrak
$\overline{\text { Penelitian ini bertujuan untuk menemukan hubungan cinta abadi dan hubungan intertekstual }}$ antara novel Laila Majnun karya Nizami dengan novel Romeo Juliet karya William Shakespeare. Pendekatan yang dilakukan dalam penelitian ini adalah pendekatan intertekstual yaitu pendekatan yang digunakan untuk menemukan aspek-aspek tertentu yang telah ada pada karya-karya sebelumnya pada karya yang muncul kemudian. Penelitian ini merupakan penelitian deskriptif kualitatif. Sasaran penelitian ini adalah menemukan hubungan keabadian cinta dan hubungan intertekstual antara novel Laila Majnun karya Nizami dan novel Romeo Juliet karya William Shakespeare. Objek penelitian ini adalah novel Laila Majunun karya Nizami dan novel Romeo Juliet karya William Shakespeare. Teknik pengumpulan data menggunakan teknik baca dan catat. Berdasarkan hasil penelitian menunjukkan bahwa Hubungan keabadian cinta antara novel Laila Majnun karya Nizami dengan novel Romeo Juliet karya William Shakespeare yang terdapat dalam penelitian ini meliputi: jatuh cinta pada pandangan pertama di usia remaja, dimabuk cinta, menutupi kisah cinta mereka, harus menderita karena cinta, berjuang untuk bisa bertemu, dan keabadian cinta. Hubungan intertekstual antara novel Laila Majnun karya Nizami dengan novel Romeo Juliet karya William Shakespeare yang terdapat dalam penelitian ini meliputi: gambaran tokoh secara fisik, tokoh Majnun dan tokoh Romeo sama-sama memiliki sahabat yang setia, pertarungan antar dua keluarga, tokoh Laki-Laki yang menyukai tokoh Laila dalam novel Laila Majnun dan tokoh Laki-Laki yang menyukai Juliet dalam novel Romeo Juliet sama-sama meninggal, keluarga Romeo dan Juliet bermusuhan sedangkan keluarga Laila dan Majnun tidak bermusuhan, Laila dan Majnun tidak sempat menikah sedangkan Romeo dan Juliet sempat menikah, tokoh Majnun diceritakan menjadi gila sedangkan tokoh Romeo tidak gila, mengasingkan dan diasingkan, tokoh Laila sempat menikah sedangkan tokoh Juliet tidak jadi menikah, kisah Laila Majnun dari dunia bagian timur sedangkan Romeo Juliet dari dunia bagian barat.
\end{abstract}

\begin{abstract}
This research aims to fine the relationship of the eternity of love and relationship intertextual between Laila majnun novel by Nizami masterpiece novel of Willian Shakespeare Romeo Juliet. The approach was conducted in this research is the intertextual approarch that is the approarch used the discover certain aspects which had existed in previous papers on the works that appeared later. This research is a descriptive qualitative research. The target of this research is to find the relationship of the eternity of love and relationship intrtextual between Laila Majnun novel work of Nizami and William Shakespeare Romeo Juliet. The object of this research is the work of Nizami Laila Majnun novel and William Shakespeare Romeo Juliet. Data collection techniques using read and write down. Based on the result of the research showed that the relationship between the novels love eternity Laila Majnun novel by Nizami works Romeo Juliet William Shakespeare contained in this studyinclude: fall in love at first sight in their teens, intoxicated of love, cover their love story, should suffer because of love, struggle to meet, and the immortality of love. The relationship amoung intertextual Laila Majnun novel by Nizami works Romeo Juliet William Shakespeare contained in this study include: the
\end{abstract}


Desta Leila Kartika dkk. / Jurnal Sastra Indonesia 7 (2) (2018)

description of the character physically, morally and Romeo Majnun both have loyal friends, a fight between two families, the male character who liked the character Laila Majnun Laila and in the novel the character man who liked Juliet in Romeo Juliet alike died the family of Romeo and Juliet, feuding while families Laila and Majnun is not hostile, Laila and Majnun didn't get married while Romeo and Juliet got married, Majnun is told to go crazy while Romeo character is not mad, alienated and isolated, the character Laila got married while the characters Juliet not so married Laila Majnun, the story of the estern part of the world while Romeo Juliet of the western world.

(C) 2018 Universitas Negeri Semarang

\author{
Alamat korespondensi: \\ Gedung B1 Lantai 1 FBS Unnes \\ Kampus Sekaran, Gunungpati, Semarang, 50229 \\ E-mail: destaleilak@yahoo.com
}

ISSN 2252-6315 


\section{PENDAHULUAN}

Persoalan percintaan dianggap menarik untuk dibahas karena cinta adalah perasaan yang ada pada setiap orang dan hampir setiap orang pasti pernah merasakannya. Cinta menurut Suyuthi (dalam Arifin, 2013:6) di dalam kitab Nawadhirul Aik fi ma'rifatin Nayk, adalah bisikan sukma, kemuliaan budi, seruan batin, keselarasan hasrat, peradaban ruh, percampuran jiwa, ketulusan hati, dan perkenalan batin. Sulaiman, keabadian adalah sesuatu yang bersifat kekal, dan keberadaannya dalam waktu tidak terhingga. Bersifat tetap tidak berubah setiap saatnya, percintaan yang sangat mendalam pasti menginginkan untuk membina percintaannya menjadi abadi. Keabadian cinta adalah suatu keinginan yang didasari pada sebuah perasaan yang muncul dalam hati dan diri manusia. Dalam hal ini rasa ingin saling memiliki, rasa ingin bersatu, dan rasa ingin bersama untuk selama-lamanya.

Seringkali pengarang menciptakan karya sastra sesuai dengan pengalamannya sendiri atau menggunakan karya sastra sebagai sarana untuk mengungkapkan perasaan yang sedang dialaminya. Karya sastra memiliki keindahan tersendiri yang menarik seseorang untuk menikmatinya. Kita dibawa ke dalam dunia imajinasi pengarang dan juga kreativitas yang di tuangkannya dalam sebuah karya sastra fiksi, salah satu nya adalah dalam sebuah novel. Dalam novel, tema adalah salah satu unsur terpenting untuk menghasilkan cerita yang menarik. Kini banyak pengarang yang menulis novel dengan tema percintaan, persoalan percintaan dianggap menarik untuk dibahas karena cinta adalah perasaan yang hampir setiap orang pernah merasakannya. Maka tidak sedikit dari penulis yang menyuarakannya lewat karya sastra.

Nizami adalah salah satu penulis yang mengangkat tema percintaan dalam salah satu karyanya yaitu novel Laila Majnun yang ditulis pada tahun 1188. Kehadiran novel tersebut diduga menjadi pencetus kemunculan karyakarya yang dihasilkan oleh pengarang pada masa selanjutnya. Salah satu novel yang sama- sama mengangkat tema percintaan namun dikemas dalam nuansa yang berbeda yaitu novel Romeo Juliet Karya William Shakespeare. Kisah Romeo Juliet untuk pertama kali diperkenalkan pada tahun 1595 di Italia.

Dalam hal ini terlihat bahwa kehadiran suatu karya sastra bisa berawal dari "pengaruh" karya sastra sebelumnya. Hal tersebut tidak dapat dipungkiri karena pada dasarnya ketika karya sastra diciptakan maka seorang pengarang pasti sudah mendapatkan pengaruh dari teksteks lain yang telah hadir sebelumnya, baik secara sadar maupun tidak sadar. Dengan demikian, ada unsur yang saling berkaitan antara penulisan karya sastra yang lahir setelahnya dengan karya yang mendahuluinya. Seperti halnya yang dikemukakan oleh Kristeva (dalam Pradopo, 2013:167) bahwa setiap teks sastra itu merupakan mosaik kutipan-kutipan, penyerapan dan transformasi teks-teks lain. Sebuah karya sastra mempunyai hubungan sejarah dengan karya sastra yang sezaman, yang mendahuluinya, ataupun yang kemudian. Hubungan ini bisa berupa persamaan ataupun pertentangan.

Berbicara tentang pengaruh dalam karya sastra, maka tidak akan terlepas dari kajian atau teori intertekstual. Dalam hubungan ini, Julia Kristeva (dalam Pradopo, 2014:233) mengemukakan bahwa tiap teks itu merupakan mosaik kutipan-kutipan dan merupakan penyerapan dan transformasi teks-teks lain. Maksudnya, tiap teks itu mengambil hal-hal yang bagus dari teks lain berdasarkan tanggapan-tangapannya dan diolahnya kembali dalam karyanya atau teks yang ditulis oleh sastrawan kemudian itu.

Tokoh Laila dan Majnun, lalu tokoh Romeo dan Juliet sama-sama melakukan perjuangan dalam menyatukan cinta mereka. Meskipun banyak sekali rintangan yang harus mereka hadapi, tapi mereka tidak menyerah. Sehingga pada akhirnya kisah cinta mereka harus berakhir dengan kematian. Kedua novel tersebut memiliki kesamaan tentang keabadian cinta diantara masing-masing tokoh. Selain dari sisi keabadian cinta diantara kedua tokoh, ada beberapa bagian dalam novel yang memiliki 
persamaan ataupun pertentangan seperti: judul, tokoh, dan aspek alur cerita.

Berdasarkan latar belakang tersebut, analisis novel Laila Majnun dan novel Romeo Juliet akan diteliti dengan fokus pada hubungan keabadian cinta dan hubungan intertekstual dengan menggunakan teori intertekstual. Dengan penelitian ini diharapkan pembaca dapat memahami bahwa kedua novel yang dijadikan objek penelitian memang memiliki hubungan baik persamaan maupun pertentangannya.

\section{METODE PENELITIAN}

Penelitian ini menggunakan pendekataan intertekstual yaitu pendekatan yang mempelajari hubungan atau keterkatian antara satu teks dengan teks lain. Hubungan antara karya sastra setelah dengan sebelumnya. Penelitian ini difokuskan tentang hubungan keabadian cinta dan hubungan intertekstualnya.

Data yang dijadikan objek dalam penelitian ini adalah penggalan wacana yang menunjukkan jalan cerita pada novel Laila Majnun karya Nizami dengan novel Romeo Juliet karya William Shakespeare. Sumber data dalam penelitian ini adalah novel Laila Majnun karya Nizami cetakan oktober 2012 dengan tebal 140 halaman diterbitkan oleh Ikhlas Media, serta novel Romeo Juliet karya William Shakespeare cetakan tahun 2010 tebal 184 halaman diterbitkan oleh Navila. Sumber data lain yang dapat mendukung adalah buku teori dan buku acuan lain yang digunakan peneliti untuk mendukung jalannya penelitian, yaitu buku tentang teori intertekstual, teori hubungan intertekstual, dan buku-buku lain yang mendukung penelitian ini.

Teknik pengumpulan data yang digunakan adalah teknik baca catat yaitu membaca dan memahami seluruh jalan cerita novel Laila Majnun karya Nizami dan novel Romeo Juliet karya William Shakespeare, kemudian mencatat hal-hal yang berkaitan dengan masalah yang akan diteliti. Pengumpulan data dalam penelitian ini yaitu dengan mencari hubungan keabadian cinta dan hubungan intertekstual antara kedua novel terebut.

Hasil analisis dideskripsikan berdasarkan data-data yang terkumpul, baik berupa kata, kalimat maupun paragraf yang terdapat dalam sumber data yakni pada novel Laila Majnun karya Nizami dan novel Romeo Juliet karya William Shakespeare. Untuk membantu dalam memahami dan menentukan suatu kasus tertentu dalam karya sastra yang diteliti diperlukan kegiatan interpertasi, misalnya untuk memahami dan menentukan mana yang merupakan hubungan keabadian cinta dan hubugan intertekstual dan mana yang bukan.

Teknik deskriptif kualitatif digunakan karena memang data-data dalam penelitian ini berupa kata, kalimat, atau paragraf yang berada di dalam cerita, sehingga bentuknya data kualitatif. Penjelasan dalam paragraf ini dilakukan secara deskriptif, dalam hal ini peneliti menampilkan penjelasan mengenai segala sesuatu yang menunjukkan adanya hubungan keabadian cinta dan hubungan intertekstual dalam novel yang dijadikan sebagai objek penelitian.

Teknik analisis data yang dimaksudkan adalah untuk mempermudah cara kerja peneliti dalam memperoleh data. Adapun langkahlangkah yang dilakukan dalam analisis data sebagai berikut: Membaca secara keseluruhan kedua novel tersebut, lalu mencatat kutipan atau hal yang merupakan jalan cerita pada kedua novel. Setelah sudah terdapat data yang menunjukkan jalan cerita pada kedua novel langkah selanjutnya membandingkan jalan cerita antara novel Laila Majnun karya Nizami dengan novel Romeo Juliet karya William Shakespeare.

\section{HASIL PENELITIAN DAN PEMBAHASAN}

Hasil penelitian tentang cinta abadi dalam novel Laila Majnun karya Nizami dan novel Romeo Juliet karya William Shakespeare kajian intertekstual disajikan dalam dua bagian permasalahan, meliputi: (1) Hubungan cinta abadi antara novel Laila Majnun karya Nizami dengan novel Romeo Juliet karya William 
Shakespeare, (2) Hubungan intertekstual antara novel Laila Majnun karya Nizami dengan novel Romeo Juliet karya William Shakespeare. Hasil penelitian berupa data deskriptif yaitu kutipan pada novel beserta penjelasannya.

Hubungan Cinta Abadi antara Novel Laila Majnun Karya Nizami dengan Novel Romeo Juliet Karya William Shakespeare

Jatuh Cinta pada Pandangan Pertama di usia Remaja

Salah satu persamaan kisah cinta pada novel Laila Majnun karya Nizami dengan novel Romeo Juliet karya William Shakespeare adalah kedua tokoh sama-sama jatuh cinta pada pandangan pertama di usia remaja.

"Bak gayung bersambut, Laila tidak jauh berbeda telah jatuh cinta kepada Qais (majnun). Api telah menyala di dalam hati mereka, dan cahayanya saling memantul di antara mereka berdua." (LM 2012:8).

"Sementara Juliet begitulah nama gadis cantik menawan itu, mengedarkan pandangan menatap setiap orang yang hadir melalui keindahan bola matanya. Tiba-tiba ia tercekat saat matanya memandang Romeo. Seketika Juliet seolah ingin memasrahkan seluruh jiwa dan raga, tanpa memperdulikan keadaan diri baik kebebasan maupun kesehatan raga." (RJ 2010:22-23).

\section{Dimabuk Cinta}

Laila dan Majnun (Qais), Romeo dan Juliet sama-sama sedang dimabukan oleh cinta. Sejak awal mereka bertemu rasa cinta diantara mereka semakin kuat, mereka selalu ingin bersama dan bertemu. Karena sudah dimabukkan oleh cinta mereka tidak memperdulikan bahaya ataupun permasalahan yang akan dihadapi, rasa cinta mereka teramat besar sehingga mengalahkan segalanya.

"Sementara sepasang kekasih ini berjemur dan bermandikan kemilau cahaya cinta mereka, meminum anggur yang memabukkan jiwa dan menikmati surga yang mempesona mata dunia dengan cemburu menyaksikan mereka berdua kala bercinta." (LM 2012:11).
"Hati yang telah menyatu akan selalu bersama walau sang kekasih pergi jauh dari pandangan. Begitulah yang terjadi antara Romeo dengan Juliet, seorang kesatria taman dan puteri jelita yang terbakar dalam kobaran api yang sama." (RJ 2010:46).

\section{Menutupi Kisah Cinta Mereka}

Dalam masalah percintaan baik Laila dan Qais (Majnun), Romeo dan Juliet sama-sama mengalami kesulitan. Permasalahan yang muncul dari sisi lingkungan, masyarakat maupun keluarga. Sehingga tidak mudah bagi mereka untuk bebas dan leluasa untuk menunjukkan hubungan percintaan yang terjalin diantara mereka.

"Qais (Majnun) dan Laila berusaha untuk tidak selalu bersua, dan tidak memandang satu sama lain untuk sementara, mereka mengunci rapat bibir mereka dan alunan syair cinta." (LM 2012:12).

"Taman itu menjadi tempat untuk menyemaikan cinta rahasia mereka. Romeo bahkan sekuat tenaga untuk tidak mendekati rumah Juliet. Namun ketika malam tiba ia melangkah dengan hati-hati mendekati rumah sang kekasih." (RJ 2010:44).

\section{Harus Menderita karena Cinta}

Begitu juga yang harus dialami oleh tokoh Laila dan Qais (Majnun) dengan Romeo dan Juliet. Mereka harus merasakan kebahagiaan sekaligus kepedihan dari cinta yang sudah mereka tanam di dalam hati masing-masing.

"Qais (majnun) adalah luka yang berjalan den berbicara, Qais adalah orang yang telah hilang, seakan dilupakan siapa saja. Qais telah dimusuhi takdir yang ditetapkan atas dirinya. Kian lama penderitaan menderanya, ia kian menjadi seperti apa yang diucapkan orang kepadanya. "Qais si Majnun, Qais si Gila!". (LM 2012:16).

"Lihatlah diriku yang tersiksa dan merana, karena memikirkan nasib cinta kita. Aku merasa hidup dan kematianku telah ditentukan untuk selalu berada di dekatmu, karena hatiku telah dirajut menjadi satu dengan hatimu, ya, hati kita telah menyatu!". (RJ 2010:48) 


\section{Berjuang untuk Bisa Bertemu}

Dalam sebuah percintaan pastilah sangat dibutuhkan sebuah perjuangan. Karena demi mendapatkan atau mencapai apa yang kita inginkan pasti perlu adanya perjuangan. Membahas mengenai perjuangan dalam kisah cinta Laila dan Qais (Majnun) ataupun kisah cinta Romeo dan Juliet keduanya sama-sama sangat berjuang untuk bisa mempertahankan cinta mereka.

"Kini Qais (Majnun) mulai tampak nyata, ia dan teman-temannya berdiri tidak jauh dari tenda Laila. Ia telah mengambil resiko yang teramat bahaya yang tidak pernah dilakukan sebelumnya." (LM 2012:20).

"Romeo mengunjungi taman rumah Juliet secara sembunyi-sembunyi untuk melihat sang kekasih dari kejauhan, agar tidak diketahui oleh orang lain. Dari taman itu ia dapat melihat wajah Juliet yang cerah, sembari menyandarkan tubuhnya di jendela." (RJ 2010:43).

\section{Cinta Abadi}

Cinta abadi yang dimaksudkan yaitu ketika tokoh Laila dan Majnun, Romeo dan Juliet berjuang untuk bisa menyatukan cinta mereka. Banyak sekali rintangan yang harus mereka hadapi, tapi karena cinta yang teramat besar mereka tetap bertahan dan memperjuangkan hingga pada akhirnya maut yang memisahkan mereka.

"Cintanya padamu tidak akan mati bersamanya, di mana pun dia berada sekarang, dia teta merindukannmu. Memang kau tidak dapat menembus tabir tanah ini dan menatap matanya, namun kau mampu kau akan melihat bahwa dia masih tetap mencari-carimu." (LM 2012:240).

"Mereka semua bahagia sekaligus bersedih karena kedamaian harus ditebus dengan cinta dan harga sebuah cinta suci yang diperlihatkan oleh Romeo dan Juliet adalah kematian." (RJ 2010:182).

Hubungan Intertekstual yang terdapat dalam Novel Laila Majnun Karya Nizami dengan Novel Romeo Juliet Karya William Shakespeare.

\section{Gambaran Tokoh Secara Fisik}

Dalam setiap novel atau karya sastra lainnya kemunculan tokoh pasti sangat diperlukan untuk menyempurnakan hasil karya yang diciptakan. Seperti pada novel Laila Majnun karya Nizami atau novel Romeo Juliet karya William Shakespeare. Selain kisah cinta yang menjadi inti dari kedua novel tersebut, tokoh sentral dalam kedua novel ini juga tidak kalah menariknya.

"Ia memperoleh seorang putra, seorang anak laki-laki yang tampan mempesona bagaikan sekuntum mawar yang rimbun berbunga, lakana sebutir berilian yang gemerlapnya dapat mengubah malam menjadi terang bercahaya." (LM 2012:4).

"Nama gadis itu adalah Laila, sebuah nama singkat yang dalam bahasa arab bearti "malam". Karena di bawah bayangan rambutnya yang hitam, wajahnya bersinar bagai rembulan yang memancarkan sinar di waktu malam." (LM 2012:7).

"Lahir seorang bocah bernama Romeo, hari berganti musim dan musim berganti tahun Romeo tumbuh menjadi seorang pemuda tampan, dengan wajah bersih, dagu lembut, dan tubuh tegap." (RJ 2010:10).

"Sementara Juliet, begitulah nama gadis cantik menawan itu mengedarkan pandangan menatap setiap orang yang hadir melalui keindahan bola matanya." (RJ 2010:22).

Tokoh Majnun dan Tokoh Romeo Sama-sama Memiliki Sahabat yang Setia

Keterkaitan lain yang terdapat dalam novel Laila Majun karya Nizami dengan novel Romeo Juliet karya William Shakespeare yaitu tokoh Majnun (Qais) dan tokoh Romeo samasama memiliki sahabat yang setia.

"Naufal menjaga agar Qais (majnun) tetap disisinya sepanjang masa, menolak berpisah dengannya walau sekejap saja. Persahabatan di antara mereka semakin terjalin erat dan kuat saja." (LM 2012:76).

"Di antara sanak keluarga dan saudara terdapat seseorang yang paling dekat, ia sering memberikan nasehat dan bersedia menemani Romeo selama bertahun-tahun. Ia menyayangi 
dan menjadi sahabat Romeo dalam suka maupun duka." (RJ 2010:14).

\section{Pertarungan antar Dua Keluarga}

Di dalam novel Laila Majnun karya

Nizami dan novel Romeo Juliet karya William

Shakespeare, memiliki persamaan lain yaitu terdapat bagian dimana diceritakan terjadi sebuah pertarungan atau perkelahian yang diakhiri dengan banyak korban berjatuhan dan harus kehilangan nyawa.

"Denting baja yang saling beradu, suara ringkik kuda yang menakutkan kalbu, jerit teriak serta rintihan memilukan keluar dari mulut orang-orang yang terluka. Di mana-mana tercium bau amis kematian." (LM 2012:82).

"Kekerasan hati melarang mereka untuk menyerah pasrah. Dengan semangat menggila mereka terlibat dalam perkelahian seru dan berusaha saling melukai lawan. Kaki-kaki bergerak gesit, tameng-tameng berkelebatan cepat. Teriakan, makian, erangan, dan jeritan terdengar keras mewarnai pertarungan itu." (RJ 2010:76).

Tokoh Laki-Laki yang Menyukai Tokoh Laila dalam Novel Laila Majnun dan Tokoh LakiLaki yang Menyukai Juliet dalam Novel Romeo Juliet Sama-Sama Meninggal

Tokoh Laila dalam novel Laila Majnun dan tokoh Juliet dalam novel Romeo Juliet samasama disukai oleh laki-laki dari keluarga yang sederajat dengan mereka. Tetapi kisah diantara mereka tidaklah mulus hingga pada akhirnya baik laki-laki yang menyukai Laila pada novel Laila Majnun dan yang menyukai Juliet pada novel Romeo Juliet harus kehilangan nyawa. Keduanya sama-sama harus berakhir dengan kematian tanpa mendapatkan cinta dari Laila maupun Juliet.

"Ibnu Salam masih muda, walaupun penyakit dan kesedihan telah melemahkannya, jasmaninya yang kokoh tetap melawan serangan baru itu. Untuk beberapa hari tampaknya ia akan bertahan. Namun kemudian nafasnya mulai melambat dan memendek, hinggga di hari keempat ruhnya meninggalkan tubuhnya dan menari terbawa angin meninggalkan dunia yang penuh kesedihan ini, dunia yang menjadi lembah air mata ini." (LM 2012:235).
"Mereka larut dalam perkelahian seru sampai akhirnya Paris terbunuh. Jantungnya tertusuk belati Romeo." (RJ 2010:171).

\section{Keluarga Romeo dan Juliet Bermusuhan Sedangkan Keluarga Laila dan Majnun Tidak Bermusuhan}

Bila pada novel Laila Majnun kedua keluarga tidak saling bermusuhan dan baik-baik saja pada awalnya, sangat berbeda dengan keadaan keluarga dalam novel Romeo Juliet. Keluarga mereka saling bermusuhan sejak dari dahulu dan susah untuk berdamai.

"Di Verona hidup dua orang bangsawan yang saling bermusuhan, yaitu tuan Capulet dan tuan Montague. Karena sesuatu hal yang menyinggung harga diri, persahabatan itu akhirnya retak kemudian pecah berubah menjadi perselihan yang mengandung api kebencian." (RJ 2010:1).

"Sejak dahulu kedua kabilah tidak pernah saling bermusuhan, oleh sebab itu AlMulawwah sangat yakin bahwa ia akan berhasil melamar Laila dan meminang." (LM 2012:27).

Laila dan Majnun Tidak Sempat Menikah Sedangkan Romeo dan Juliet Sempat Menikah

Ada yang membedakan kedua novel tersebut, karena bila pada novel Laila Majnun mereka tidak sempat untuk menikah, sedangkan pada novel Romeo Juliet mereka sempat menikah meskipun pada akhirnya mereka harus dipisahkan karena keadaan.

"Sepasang kekasih itu menyatakan bahwa pernikahan ini merupakan keinginan dari mereka. Pastor melihat mereka berdua telah terikat cinta yang kuat, lalu Pastor mengucapkan syukur atas janji pernikahan yang telah mereka ucapkan, dan memberikan beberapa nasehat penting untuk sepasang pengantin." (RJ 2010:62).

\section{Tokoh Majnun Diceritakan Menjadi Gila}

\section{Sedangkan Tokoh Romeo Tidak Gila}

Banyak sekali cobaan yang harus mereka hadapi hanya untuk bisa bersatu dan menunjukkan cinta mereka. Tetapi ternyata tokoh Majnun dalam novel Laila Majnun tidak sanggup lagi untuk menghadapi cobaan yang datang silih berganti dan mengakibatkan dirinya menjadi kehilangan akal sehat. 
"Qais telah dimusuhi takdir yang ditetapkan atas dirinya. Kian lama penderitaan menderanya, ia kian menjadi seperti apa yang diucapkan orang kepadanya, "Qais si Majnun, Qais si gila!.” (LM 2012:16).

\section{Mengasingkan dan Diasingkan}

Kisah percintaan pada novel Laila Majnun dan novel Romeo Juliet memang penuh dengan tragedi dan kejadian tidak terduga.

"Ia harus menyendiri bersama kesedihannya dan tempat terpencil yang hanya terdiri dari pasir dan bebatuan di tengah-tengah gunung dan jurang adalah satu-satunya tempat yang cocok baginya." (LM 2012:56).

"Hanya karena harus menjalani hukuman pengasingan, engkau terlihat sangat gelisah. Engkau menyesal karena harus pergi dari tanah kelahiran dan menninggalkan semua sahabat karibmu. Engkau takut meninggalkan gadis yang menjaga hatimu dan sulit berpisah dengan banyak kesenangan yang telah engkau rasakan." (RJ 2010:102).

\section{Tokoh Laila Sempat Menikah Sedangkan Tokoh Juliet Tidak Jadi Menikah}

Konflik yang terjadi dalam kedua novel bukan hanya dialami oleh tokoh laki-lakinya saja, tetapi tokoh wanita juga mengalaminya.

"Lebih baik aku meminum ramuan bapa, daripada jatuh ditangan pemuda itu! Ia tidak berhak atas sebagian tubuhku maupun seluruhnya, juga cintaku. Aku harus menghadapi semua bahaya menghadang mengancam, demi kesabaran dan harapan untuk hidup bersama Romeo."

"Lalu hari pernikahan pun tiba, matahari menghamparkan jubah cahayanya ke atas pundak malam seperti orang yang mengerudungi sepasang pengantin muda. Ayah Laila bangun pagi-pagi sekali, tidak sabar untuk menyelesaikan persiapan pernikahan itu, dan ketika siang tiba semuanya sudah siap." (LM 2012:119).

Kisah Laila Majnun Dari Dunia Bagian Timur Sedangkan Romeo Juliet Dari Dunia Bagian Barat

Banyak orang mengatakan dunia dibagi oleh dua peradaban besar, yaitu Timur dan Barat. Dalam hal cerita Timur memiliki simbol cinta sejati yaitu Qais (Majnun) dan Laila, sedangkan Barat memiliki Romeo dan Juliet. Bila kisah Laila Majnun banyak mempersoalkan jiwa cinta, Romeo Juliet justru menghadirkan kisah kehidupan dua pecinta. Laila Majnun berbicara secara mendalam jiwa pecinta, sedang Romeo Juliet bicara soal hambatan dalam mewujudkan cinta.

\section{PENUTUP}

1. Novel Laila Majnun karya Nizami mempunyai hubungan intertekstual dengan novel Romeo Juliet karya William Shakespeare. Hubungan intertekstual tersebut bisa dilihat dari struktur yang sama mulai dari pemilihan tema, alur (jalan cerita), dan tokoh dalam kedua novel di atas.

2. Novel Laila Majnun karya Nizami dan novel Romeo Juliet karya William Shakespeare memiliki pengaruh dalam penciptaannya. Novel Laila Majnun merupakan hipogram dari kelahiran novel Romeo Juliet. Pengarang dari novel Laila Majnun yaitu Nizami Ganjavi merupakan salah satu tokoh sastra yang mempengaruhi pengarang novel Romeo Juliet yaitu William Shakesperae.

\section{DAFTAR PUSTAKA}

Arifin, Gus. 2013. Menikah untuk bahagia. Jakarta: PT Elex media komputindo.

Fanjavi, Nizami. 2012. Laila Majnun. Bandung: Ikhlas Media.

Mendambakan Keabadian dalam Kehidupan. (http://ienahudin.wordpress.com). Sulaiman Weblog. Diunduh pada 14 juni 2016 jam 23:11.

Nurgiyantoro, Burhan. 1998. Teori Pengkajian Sastra. Yogyakarta: Gadjah Mada University Press.

Pradopo, Rachmat Djoko. 2014. Pengkajian Puisi. Yogyakarta: Gadjah Mada University Press.

Pradopo, Rachmat Djoko. 2013. Beberapa Teori Sastra, Metode Kritik, dan Penerapannya. Yogyakarta: PustakaPelajar.

Shakespeare, William. 2010. Romeo Juliet. Yogyakarta: Navila. 